\title{
Trends in Educational Research about Social Attitudes Education and Learning: A Systematic Literature Review
}

\author{
Hengki Wijaya", Arismunandar, Hamsu Abdul Gani \\ Department of Education Science, Universitas Negeri Makassar, South Sulawesi, Indonesia
}

Received October 7, 2020; Revised November 17, 2020; Accepted December 11, 2020

\section{Cite This Paper in the following Citation Styles}

(a): [1] Hengki Wijaya, Arismunandar, Hamsu Abdul Gani, "Trends in Educational Research about Social Attitudes Education and Learning: A Systematic Literature Review," Universal Journal of Educational Research, Vol. 8, No. 12A, pp. 7682 - 7693, 2020. DOI: 10.13189/ujer.2020.082555.

(b): Hengki Wijaya, Arismunandar, Hamsu Abdul Gani (2020). Trends in Educational Research about Social Attitudes Education and Learning: A Systematic Literature Review. Universal Journal of Educational Research, 8(12A), 7682 7693. DOI: 10.13189/ujer.2020.082555.

Copyright $\bigcirc 2020$ by authors, all rights reserved. Authors agree that this article remains permanently open access under the terms of the Creative Commons Attribution License 4.0 International License

\begin{abstract}
Until now, learning is still focused on the cognitive realm only. One aspect that is often neglected is social attitudes, which are part of the affective aspect that has an essential role in social life. The limited number of researchers who touch on this area makes reference sources of social attitudes still limited. This study is a Systematic Literature Review (SLR) using the PRISMA model. This model is considered a reasonably comprehensive model because it has four main stages: identification, screening, eligibility, and inclusion. Researchers collected data from various open access data sources such as Google Scholar, Web of Science (WoS), Scopus, ERIC, Researchgate.net, Academia.com, and Sciencedirect.com. Furthermore, the data were analyzed using content analysis techniques in obtaining an overview of trends and implications of research on education and learning social attitudes over the past ten years. The results showed that there were only 14 articles that met the criteria for further analysis. The fourteen articles discuss several main research topics, such as (1) improving students' social attitudes through learning models/approaches/methods, (2) learning social attitudes in the context of inclusive education, (3) developing and validating social attitude instruments, and so on other. These findings indicate the need for further and more comprehensive research on learning social attitudes so that this aspect is increasingly understood by various elements of education as an aspect that is as important as the cognitive aspect.
\end{abstract}

Keywords Social Attitudes, Education, Social Attitudes Learning, Systematic Literature Review (SLR)

\section{Introduction}

Education is an important factor in human life to develop cognitive, affective, and psychomotor aspects. But in fact, there is still much education in various countries that focus on one aspect only. The cognitive aspect is the most dominating aspect and is considered the single most crucial aspect for humans. Effective and psychomotor factors also contribute a lot to individual success in life.

Affective is an essential aspect of students' development, often ignored by educators in the learning process. This aspect has a significant contribution to the social life of students. This means that the affective part plays an essential role in shaping individual attitudes and behaviour in social interactions in society [1]. Therefore, education is considered a very appropriate socialization agent about attitudes and behaviour as social class indicators. Also, education is empirically proven to have a liberalizing effect on social attitudes that are not related to non-economic problems [2]. Thus, social attitudes have a significant role to be developed for students in their educational environment.

In simple terms, social attitude is an individual's 
tendency to act [3]. This attitude is part of the affective domain and has an important role in learning [4]. But in fact, it is precisely this domain that is rarely integrated into learning and is often even ignored by teachers [5]. Ahmadi [6] states that social attitude is the individual's awareness in determining the real, repeated action of certain social objects. That is, social attitudes are also interpreted as a form of one's response to social items.

The aspect of social attitudes for students is seen by some experts as still very low [5]. This can be seen in several activities in class that are frequently encountered, such as (a) the number of students who are embarrassed to speak, (b) answering teacher questions in a shy and low voice, (c) disturbing friends, and (d) using harsh words. This situation causes students to be less able to interact effectively with the surrounding environment. They tend to think that aggressive action is the most appropriate way to solve social problems and get what they expect.

In the context of higher education, social attitudes also need to be adequately empowered. A study states that many students do not have a sense of responsibility $(35.97 \%)$, do not respect friends who have different backgrounds in religion, race, culture, and gender $(30.70 \%)$, and some students do not want to cooperate with groups from other ethnicities (34.21\%) [7]. Even firmly, Parke \& Clarke-Stewart also stated that students who have a social attitude would establish good cooperation in achieving learning goals.

This condition is the background of the importance of learning and teaching social attitudes for students. As we know, life's needs and problems are increasingly complex, diverse, and have a powerful influence on humans today. This condition certainly has a psychological impact, and if it is not controlled, it will cause friction or even conflict between individuals. For this reason, the need for social-psychological adaptation of the personality of modern society is increasingly urgent to be applied [8]. One of them is by providing social attitude education for children and adolescents.

Many teachers and researchers have carried out the study of learning social attitudes on a local scale. A study states that the cooperative learning model can foster maximum social attitudes for students [9]. Another study claims that teachers have applied various assessment techniques to assess social attitudes, such as observation, self-assessment, peer-to-peer assessment, and journal-based assessment [10].

Apart from these two studies, several researchers have also conducted studies on classroom action research. Nurasiah [11] found the fact that Classroom Action Research (CAR) can improve social attitudes by using the Value Clarification Technique (VCT) learning model. A similar study also states that CAR using cooperative learning models positively impacts increasing social attitudes through 2 cycles [12]. Apart from CAR, research and development methods are also used by researchers in developing social attitudes assessment instruments in social studies subjects [13]. In this R \& D study, there are two aspects of social attitudes that the assessment instrument has developed: polite and tolerant attitudes when interacting with peers.

\section{Literature Review}

\subsection{Social Attitudes}

Attitude is an important issue because a person's attitude will characterize the person's behavior. Attitudes to humans are formed continuously throughout their life. Attitude has a significant role to play in determining behavior or making decisions about an object of the problem [14]. Attitude is a response to acting on the stimulus that occurs. Therefore, the form of attitude cannot be seen but must be interpreted from the reaction [15]. According to Azwar [16], it is explained that a person's attitude towards an object is a feeling or emotion, and the second factor is a response to react positively (like) or negatively (do not like) to something. Thus, attitude is a person's conscious response to the problems faced throughout his life. In other words, attitudes can form a commitment that, if done continuously, will become a character.

Sudarsono defines social attitudes as actions or firm attitudes from a person or group in the family or society. Social attitudes can be positive or negative, depending on the environment's influence and one's acceptance [17]. Social attitude is the individual's awareness to act realistically and repeatedly against certain social objects [14]. Thus, the definition of social attitudes is a person's awareness to commit to doing realistically and continuously in their social interactions in family, school, society, and their environment.

Experts and psychologists already believe that social attitudes play an essential role in predicting human behavior [18]. Initially, social attitudes were introduced by experts to the social sciences and have become one of the central constructs to predict and explain in the domain of social psychology and become the focus of research. Social attitudes do not occur in isolation but are linked together in a recognizable pattern to form an ideological construction [19].

The factors that influence social attitudes are divided into two, namely, internal factors and external factors. Internal factors are contained in the human person himself. This factor is in the form of an individual's selective attitude to accept and process influences from outside. On the other hand, external factors are factors that are outside the human person [6].

Vygotsky's theory states that social interaction helps students' thinking and understanding because development and learning occur in a social context. The activities of exchanging ideas and learning from each other in collaborative learning have involved students in 
structuring their thoughts and increasing their understanding through social interaction with friends in groups so that learning becomes more efficacious [20], [21]. Helaluddin \& Fransori [22] stated that education is not only sharing knowledge (knowledge) to students but also sharing moral values and universal human values. Thus, students can respect others' lives reflected in their behavior and self-actualization, from elementary school age to adulthood, to become good citizens [23].

Social attitudes can be seen in a person's activities in working together with other people, peers, and teachers [24]. Therefore, the assessment of social attitudes is carried out by observing students during the learning process. Social attitude competency assessment is an assessment carried out by the teacher to measure the level of attainment of the competence of social attitudes of students, which includes aspects, accepting or paying attention to (a) receiving or attending (b) responding, (c) organizing or managing, and d) having the character [25].

In the learning process, it can be described that the most dominant attitude that appears in learning is social attitudes. Social attitudes are attitudes that determine how individuals face other individuals in society against existing social objects. Aspects of social attitudes include honesty, discipline, responsibility, care, courtesy, and responsibility. Assessment benchmarks are indicators because indicators are a sign of the achievement of competency. Indicators must be measurable. In attitude assessment, indicators are signs that the teacher can observe students. The indicators that can be used to assess social attitudes based on the 2013 Curriculum are honesty, discipline, responsibility, tolerance, cooperation, politeness, and self-confidence [26].

\subsection{Systematic Literature Review}

In recent years, many researchers have started to use the literature review method in carrying out their research. There are two types of literature reviews, namely traditional reviews or narrative reviews and Systematic Literature Reviews (SLR), or what is often referred to as "the gold standard" [27]. Researchers have begun to abandon traditional reviews and turn to SLR-type reviews.

SLR is a review method that provides a methodological approach in mapping existing research evidence on a particular topic. Besides mapping research evidence, SLR also assesses and synthesizes the studies' results it reviews [28] [29]. A similar statement was also made by Jin \& Bridges [30] who stated that a good SLR provides a critical synthesis of research articles, identifies the knowledge, highlights gaps, provides guidance and ultimately offers a new perspective for future studies.

At the beginning of its appearance, SLR originated and is widely used in medical science. However, in its development, SLR is also used in social sciences such as education and management in a scientifically replicated and transparent manner [31] [32]. Studies utilizing the
SLR method will be systematic, explicit, comprehensive, and reproducible with transparent descriptions. This condition makes it possible for the researchers to decide whether the review's conclusions that have been carried out can be valid and reliable [33].

Experts suggest several sets of guidelines that researchers should follow. Fernadez-Ríos and Casal [34] offer a set of guidelines in structuring and justifying content consisting of (a) article organization, (b) understanding the background of the topic, (c) literature review, (d) style and understanding of argumentative structures, and (e) the theoretical and practical relevance of the article. An SLR usually lists things, such as research design, the main features of the existing research, describes the literature base's quantity and quality, and compiles current research in the graphical form [35].

One example of SLR that is widely used today is PRISMA or Preferred Reporting Items for Systematic Review \& Meta-analysis. This model consists of a series of evidence-based items that guide the implementation and reporting of a systematic review [36]. On the other hand, Handayani [37] set several stages for researchers in writing articles using the PRISMA method. These stages include: (a) establishing eligibility criteria or inclusion and exclusion criteria, (b) determining the source of information from which the data was obtained, (c) selecting literature/research articles, (d) collecting data, and (e) extracting data.

\subsection{Purpose of the Study}

The variety of research on social attitudes is considered unable to provide a comprehensive understanding of teachers and researchers about the importance of learning social attitudes. A global literature review is needed that reviews the latest findings on this topic from around the world. Thus, this study is aimed at completing the gaps that occur regarding education and learning social attitudes. Based on this description, the research questions include the following points: (1) what the current research trend on learning social attitudes is? (2) what are future implications for learning social attitudes due to the existing research's objectives and limitations?

\section{Research Methodology}

\subsection{Research Design}

This study uses a theoretical study method called the Systematic Literature Review (SLR) based on the background previously described. This research design is the newest approach adopted by researchers/experts to analyze research results in various reputable journals with different themes [38].

SLR aims to collect and analyze various data sources that are then synthesized to obtain a comprehensive 
picture of the importance of learning social attitudes for students [39] [40] [41]. The synthesis process in this SLR study also allows researchers to see the intervention's effectiveness, identify knowledge gaps that require further research, and note consistency and variation in the field [42]. This study uses the type of SLR with PRISMA type, as has been widely recommended by experts \& researchers [43] [44] [45].

\subsection{Search Methods}

In this study, the scope is deliberately limited to the context of education and learning social attitudes to ensure that there are aspects of its feasibility. In collecting data in research articles, several databases were selected, such as ERIC, Scopus, Google Scholar, Web of Science (WoS), Researchgate.net, Academia.com, and Sciencedirect.com. The search terms or keywords used in the article's search were social attitudes, social attitude education, and social attitude teaching/learning. More clearly, the data search flow can be illustrated as in Figure 1.

\subsection{Screening Criteria}

The screening process begins by reading carefully the titles and abstracts of the journal articles that have been collected. After that, the researcher provides an assessment of whether the journal article is worthy of analysis or not. The assessment is carried out using several criteria known as inclusion criteria and exclusion criteria. Each journal article is evaluated to identify the existence of education, teaching, and learning social attitudes for students.

Table 1. Criteria used in assessing journal articles

\begin{tabular}{ccc}
\hline No & Inclusion Criteria & Exclusion Criteria \\
\hline 1. & $\begin{array}{c}\text { English-language national } \\
\text { and international journal } \\
\text { articles }\end{array}$ & $\begin{array}{c}\text { Articles in Indonesian/other } \\
\text { than English }\end{array}$ \\
\hline 2. & $\begin{array}{c}\text { Discusses social attitudes } \\
\text { in the context of teaching } \\
\text { and learning }\end{array}$ & $\begin{array}{c}\text { Themes outside the context of } \\
\text { teaching and learning }\end{array}$ \\
\hline 3. & $\begin{array}{c}\text { Articles published in } \\
\text { national/international } \\
\text { scientific journals }\end{array}$ & $\begin{array}{c}\text { Articles are published in } \\
\text { addition to scientific journals, } \\
\text { such as proceedings, final } \\
\text { assignments, and others }\end{array}$ \\
\hline 4. & $\begin{array}{c}\text { Published from } \\
2010-2020\end{array}$ & Articles published before 2010 \\
\hline
\end{tabular}

\subsection{Data Analysis}

To get an SLR with good quality, the researchers chose and used the PRISMA guidelines. This guideline was selected because it has a checklist and flow chart capable of improving a systematic review [46]. Furthermore, to ensure the quality of this SLR, the selection of journal articles for further analysis must be based on the framework's criteria. As part of the systematic review process, inclusion and exclusion criteria were determined to identify which articles to include or exclude from the study [47].

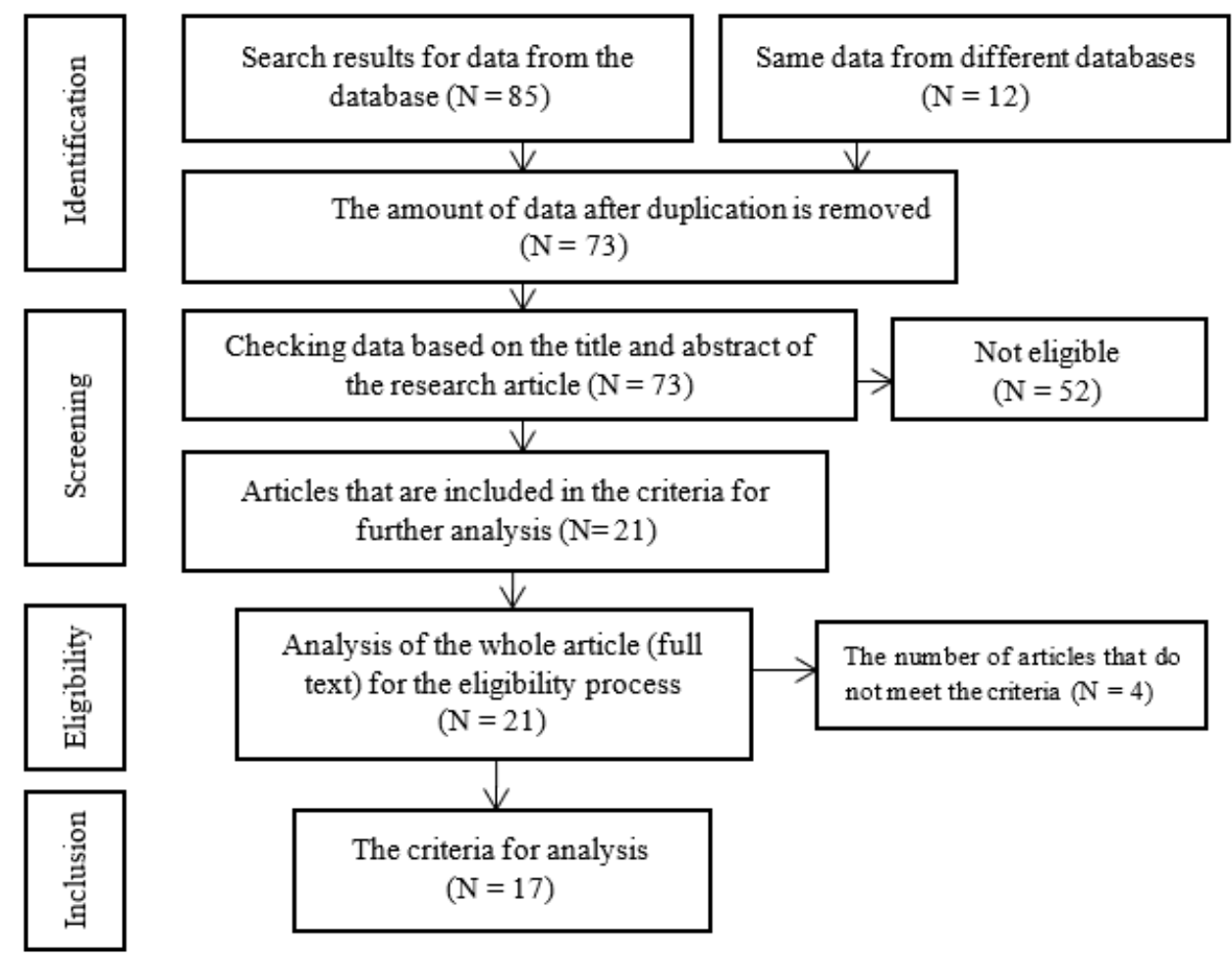

Figure 1. Flowcharts of SLR Process 
All selected articles were extracted by the first researcher using the extraction form that had been made. The extraction form consists of several details of the articles analyzed, namely: (a) author, (b) year of publication, (c) country, (d) focus/research objective, (e) research design/methodological approach, (f) participants, (g) data collection, (h) data analysis approach, (i) theoretical/conceptual framework, (j) evaluation, and (k) main findings [48]. After that. The second and third researchers reviewed the extraction results from the first researcher. The process is carried out to provide confidence. The data have been extracted in the same way by each author.

Furthermore, articles that enter the extraction phase are analyzed using content analysis techniques. The use of this analysis technique aims to determine research trends at the descriptive level that explores a particular theme [49]. In this analysis technique, three stages must be done by the researcher, namely coding, grouping based on equations, and data abstraction [50].

\section{Result}

After passing through the identification, screening, and eligibility phases, 17 journal articles were further analyzed. The seventeen articles met the requirements set by the researchers on the inclusion and exclusion criteria. All articles that enter this final phase come from various countries, including Indonesia. The identity of these articles can be seen in table 2 .

Table 2. The identity of the journal being analyzed

\begin{tabular}{|c|c|c|c|}
\hline No & Article Title & Author(s) & Journal Name \\
\hline 1. & $\begin{array}{l}\text { Development of students' social attitudes in biology } \\
\text { classroom through jigsaw and guided inquiry (A1) }\end{array}$ & $\begin{array}{l}\text { Mursito Bialangi, Siti Zubaidah, } \\
\text { Mohamad Amin, \& Abdul Gofur } \\
\text { (2016) }\end{array}$ & $\begin{array}{l}\text { International Journal of } \\
\text { Academic Research and } \\
\text { Development }\end{array}$ \\
\hline 2. & $\begin{array}{l}\text { Professional self and Social attitudes towards } \\
\text { disability: A comparison between curricular and } \\
\text { special needs teachers (A2) }\end{array}$ & M. E. De Caroli \& E. Sagone (2011) & $\begin{array}{l}\text { International Journal of } \\
\text { Developmental and } \\
\text { Educational Psychology }\end{array}$ \\
\hline 3. & $\begin{array}{c}\text { Epistemological beliefs and mediating role of } \\
\text { learning approaches on social attitudes of SHS } \\
\text { students (A3) }\end{array}$ & M. Nur Ghufron (2020) & $\begin{array}{l}\text { Universal Journal of } \\
\text { Educational Research }\end{array}$ \\
\hline 4. & $\begin{array}{c}\text { The development of social attitudes assessment } \\
\text { instrument and social studies learning outcomes } \\
\text { grade IV on the theme of the beauty of diversity in } \\
\text { my country (A4) }\end{array}$ & $\begin{array}{l}\text { Ikrima Maulida, I Ketut Dibia, \& I } \\
\text { Gede Astawan (2020) }\end{array}$ & $\begin{array}{l}\text { Indonesian Journal of } \\
\text { Educational Research and } \\
\text { Review }\end{array}$ \\
\hline 5. & $\begin{array}{c}\text { The development of social attitudes through } \\
\text { cooperative learning model methods in social } \\
\text { studies education subjects in public junior high } \\
\text { school 1 Batang (A5) }\end{array}$ & $\begin{array}{l}\text { Hindah W. Hardiningtiastuti, Ari Tri } \\
\text { Soegito, \& Murwatiningsih (2018) }\end{array}$ & $\begin{array}{l}\text { Journal of Educational Social } \\
\text { Studies }\end{array}$ \\
\hline 6. & $\begin{array}{c}\text { Improving social attitudes and knowledge through } \\
\text { role playing method (A6) }\end{array}$ & $\begin{array}{l}\text { Tati Arifah Nurdin, M. Japar, Ishak G. } \\
\text { Bahtiar (2018) }\end{array}$ & $\begin{array}{l}\text { American Journal of } \\
\text { Educational Research }\end{array}$ \\
\hline 7. & $\begin{array}{l}\text { The spiritual and social attitudes of students } \\
\text { towards integrated problem-based learning models } \\
\text { (A7) }\end{array}$ & $\begin{array}{c}\text { Suhaedir Bachtiar, Siti Zubaidah, } \\
\text { Aloysius Duran Corebima, \& Sri } \\
\text { Endah Indriwati (2018) }\end{array}$ & Issues in Educational Research \\
\hline 8. & $\begin{array}{l}\text { Assessment of the social attitudes of primary school } \\
\text { students (A8) }\end{array}$ & Ari Setiawan \& Siti Suardiman (2018) & $\begin{array}{l}\text { Research and Evaluation in } \\
\text { Education }\end{array}$ \\
\hline 9. & $\begin{array}{c}\text { Emotional intelligence, religiosity, and social } \\
\text { attitudes of students (A9) }\end{array}$ & Rijal Firdaos (2017) & Jurnal Pendidikan Islam \\
\hline 10. & $\begin{array}{c}\text { The social attitudes empowerment of biology } \\
\text { students: Implementation JiRQA learning strategy } \\
\text { in different ethnics (A10) }\end{array}$ & $\begin{array}{c}\text { Yakobus Bustami, Aloysius Duran } \\
\text { Corebima, Endang Suarsini, \& } \\
\text { Ibrohim (2017) }\end{array}$ & $\begin{array}{l}\text { International Journal of } \\
\text { Instruction }\end{array}$ \\
\hline 11. & $\begin{array}{c}\text { Social attitudes and initial teacher education for } \\
\text { special education (A11) }\end{array}$ & $\begin{array}{c}\text { Josiane Pereira Torres \& Eniceica } \\
\text { Goncalves Mendes (2019) }\end{array}$ & $\begin{array}{c}\text { Revista Brasileira De Educacao } \\
\text { Especial }\end{array}$ \\
\hline 12. & $\begin{array}{l}\text { Social attitudes of Turkish towards participation in } \\
\text { physical education and sport (A12) }\end{array}$ & Mehmet Goral (2011) & $\begin{array}{c}\text { Social Behavior and } \\
\text { Personality } \\
\end{array}$ \\
\hline 13. & $\begin{array}{l}\text { Construct validation of a general social attitudes } \\
\text { scale (A13) }\end{array}$ & $\begin{array}{c}\text { Goran Milas, Boris Mlacic, \& Igor } \\
\text { Miklousic (2013) } \\
\end{array}$ & Journal of Individual Deference \\
\hline 14. & $\begin{array}{l}\text { Accessibility of People with Disabilities to Higher } \\
\text { Education: Social Attitudes of Students and } \\
\text { professors of a Higher Education Institutions (A14) }\end{array}$ & $\begin{array}{l}\text { Jane A. Brunhara, Ana P. Berberian, } \\
\text { Ana C. Guarinello et al. (2019) }\end{array}$ & $\begin{array}{l}\text { Revista Cefac: Speech, } \\
\text { Language, Hearing Sciences } \\
\text { and Education Journal }\end{array}$ \\
\hline 15. & $\begin{array}{l}\text { Development of Social Studies Learning Model } \\
\text { Based on Local Wisdom in Improving Students' } \\
\text { Knowledge and Social Attitude (A15) }\end{array}$ & $\begin{array}{l}\text { Sarnely Uge, Amos Neolaka, \& } \\
\text { Mahmuddin Yasin (2019) }\end{array}$ & $\begin{array}{l}\text { International Journal of } \\
\text { Instruction }\end{array}$ \\
\hline 16. & $\begin{array}{c}\text { The Teacher's Role in Developing Student Social } \\
\text { Attitude (A16) }\end{array}$ & $\begin{array}{c}\text { Arsita Yunia Sarwono, Murtono \& } \\
\text { Eka Widianto (2020) }\end{array}$ & $\begin{array}{l}\text { International Journal of } \\
\text { Elementary Education }\end{array}$ \\
\hline 17. & $\begin{array}{c}\text { Superflex: Innovative Learning to Develop Social } \\
\text { Attitude Competencies (A17) }\end{array}$ & $\begin{array}{l}\text { Huriah Rachmah, Rudi Gunawan \& } \\
\text { Jajang Hendar Hendrawan (2018) }\end{array}$ & $\begin{array}{l}\text { International Journal of } \\
\text { Elementary Education }\end{array}$ \\
\hline
\end{tabular}


Table 3. Methods, instruments and participants

\begin{tabular}{|c|c|c|c|}
\hline $\begin{array}{c}\text { Article } \\
\text { Code }\end{array}$ & Research Method & Data Collection/Instrument & Partisipant \\
\hline A1 & Quantitative/Quasi experiment & Pre-test \& post-test questionnaires & 70 high school students in Palu City, Indonesia \\
\hline A2 & Quantitative with the help of SPSS & $\begin{array}{l}\text { Closed questionnaire and open } \\
\text { questionnaire }\end{array}$ & $\begin{array}{c}45 \text { curriculum teachers and } 45 \text { teachers of } \\
\text { children with special needs at secondary } \\
\text { schools in Catania }\end{array}$ \\
\hline A3 & Quantitative using SEM & A scale questionnaire & $\begin{array}{c}177 \text { respondents from Bae District, Kudus, } \\
\text { Central Java, Indonesia }\end{array}$ \\
\hline A4 & $\begin{array}{l}\text { Research \& Development with the } \\
\text { 4D model }\end{array}$ & Validation questionnaire & 113 students on the trial test and two experts \\
\hline A5 & Qualitative & $\begin{array}{l}\text { Observation, interview, and } \\
\text { documentation techniques }\end{array}$ & $\begin{array}{l}\text { Student of Yunior High School } 1 \text { state Batang, } \\
\text { Central Java, Indonesia }\end{array}$ \\
\hline A6 & Action Research/qualitative & $\begin{array}{c}\text { Observations, interviews, tests, } \\
\text { recordings }\end{array}$ & $\begin{array}{c}32 \text { fourth grade students of SD Negeri } \\
\text { Jatibening Bekasi, West Java, Indonesia }\end{array}$ \\
\hline A7 & Quantitative/quasi-experimental & $\begin{array}{c}\text { Observation, self-assessment, and } \\
\text { peer-assessment, pretest \& posttest }\end{array}$ & $\begin{array}{c}\text { Students at four schools in Jeneponto, Binamu, } \\
\text { Batang, and Tamalatea, Indonesia }\end{array}$ \\
\hline A8 & Qualitative & $\begin{array}{c}\text { Direct disclosure and observation } \\
\text { questionnaires }\end{array}$ & 58 grade IV \& V Elementary School students \\
\hline A9 & Survey/quantitative & Questionnaire & $\begin{array}{c}125 \text { students majoring in Islamic education, } \\
\text { semester VI }\end{array}$ \\
\hline $\mathrm{A} 10$ & Quasi-experiment & $\begin{array}{l}\text { Student Social Attitude } \\
\text { questionnaire (SSA) }\end{array}$ & $\begin{array}{c}125 \text { students from different ethnic groups } \\
\text { (Dayak, Malay, and Javanese) }\end{array}$ \\
\hline A11 & Quantitative & A questionnaire with a Likert scale & 88 Students \\
\hline A12 & Quantitative & Questionnaire & 600 students ( 338 girls $\& 262$ boys) \\
\hline A13 & Qualitative & $\begin{array}{c}\text { A General Social Attitude Scale } \\
\text { using two attitude scales containing } \\
25 \text { item questions } \\
\end{array}$ & 452 students ( 227 girls $\& 223$ boys) \\
\hline A14 & Quantitative & Questionnaire & 601 academics, 583 students, \& 18 professors \\
\hline A15 & Quantitative & $\begin{array}{c}\text { Questionnaire, tests, \& observation } \\
\text { sheet }\end{array}$ & 18 Experts, 130 students, \& 8 teachers \\
\hline A16 & Qualitative & $\begin{array}{c}\text { Observation, interview, and } \\
\text { documentation }\end{array}$ & 19 students \\
\hline A17 & $\begin{array}{l}\text { Qualitative with descriptive } \\
\text { analysis techniques }\end{array}$ & Article, books, research reports & $\begin{array}{l}\text { Research results or research articles related to } \\
\text { the topic }\end{array}$ \\
\hline
\end{tabular}

In addition to describing the identity of journal articles in general, the author also reviews in detail the methods, data collection instruments, and the participants involved. The description in this section aims to provide the reader with an overview of the research methods' trends. Thus, readers can find out the trend of previous researchers' research methods during the last ten years. The table 3 presents the types of research methods, instruments, and participants involved in the fourteen articles.

In the last ten years, the dominance of research in teaching and learning social attitudes uses a more quantitative approach. Eight research articles use this approach, such as quasi-experiments, survey research, and others. Furthermore, research with a qualitative approach is also quite widely used by researchers in reviewing this topic. The type of qualitative approach used is in the form of Classroom Action Research (CAR) and other types of qualitative methods. Research \& Development (R \& D) was also used by one of the research articles that designed and developed a questionnaire to measure students' social attitudes. In general, the research methods used have used all available techniques, but the distribution of their use is still uneven.

\section{Discussion}

From table 4, it can be drawn the main points, which are the themes or research topics in the field of learning social attitudes at the school and college levels. The majority of articles discuss learning social attitudes using specific learning models, strategies, and methods. Several learning models/approaches applied to improve social attitudes in these studies include the Jigsaw model and guided inquiry [9], the cooperative learning model [51], [52], JiQRA learning strategies [53], problem-based learning [54], model Superflex [55], and role-play strategies [5].

Another theme raised in several studies in the last ten years is related to social attitudes towards inclusive education. Three research articles portray social attitudes associated with the world of inclusive education. The three studies use a quantitative approach to finding answers to their research questions. First, research was conducted by Torres and Mendes [4] which captures the social attitudes of prospective teacher students in separate rooms and one room. Another study conducted by De Caroli and Sagone [56] attempted to reveal the 
relationship between curriculum teachers and teachers of children with special needs to students with disabilities. Finally, a quantitative study that examines the relationship between social professors, male students, and female students about their satisfaction with inclusive education practice so far [57].

Table 4. Themes and research findings

\begin{tabular}{|c|c|c|}
\hline $\begin{array}{l}\text { Article } \\
\text { Code }\end{array}$ & Research Topic & Research Finding \\
\hline A1 & $\begin{array}{l}\text { Increasing students' social attitudes in learning biology with the } \\
\text { Jigsaw Model }\end{array}$ & $\begin{array}{l}\text { - There is no difference in the social attitudes of } \\
\text { high school students who are taught using the } \\
\text { Jigsaw model and guided inquiry }\end{array}$ \\
\hline A2 & $\begin{array}{l}\text { Self-professionalism and social attitudes between curriculum } \\
\text { teachers and teachers for children with special needs }\end{array}$ & $\begin{array}{l}\text { - This means that the two learning models have the } \\
\text { same potential }\end{array}$ \\
\hline A3 & $\begin{array}{l}\text { Epistemological beliefs and mediating the role of learning } \\
\text { approaches for students' social attitudes (tolerance) }\end{array}$ & $\begin{array}{l}\text { - With regards to emotions, curriculum teachers are } \\
\text { assumed to have negative feelings towards } \\
\text { students with disabilities while ABK teachers } \\
\text { show the opposite }\end{array}$ \\
\hline A4 & Development of social attitude instruments & $\begin{array}{l}\text { - Professional self-representation is significantly } \\
\text { more positive than that expressed for students } \\
\text { with disabilities }\end{array}$ \\
\hline A5 & Learning social attitudes through cooperative learning models & $\begin{array}{l}\text { - } \begin{array}{l}\text { Belief in knowledge and confidence in learning } \\
\text { affects deep approaches and surface (deep \& } \\
\text { surface) }\end{array} \\
\end{array}$ \\
\hline A6 & Learning social attitudes through role-playing methods & $\begin{array}{l}\text { The results of the validation of the student's social } \\
\text { attitude instrument were } 1.00 \text { and categorized as } \\
\text { very high }\end{array}$ \\
\hline A7 & $\begin{array}{l}\text { Learning spiritual and social attitudes through problem-based } \\
\text { learning models and Number Head Together (NHT) }\end{array}$ & $\begin{array}{l}\text { - There are differences in the spiritual and social } \\
\text { attitudes of students with different academic } \\
\text { abilities towards other learning models }\end{array}$ \\
\hline A8 & Assessment of elementary school students' social attitudes & $\begin{array}{l}\text { The integrated PBL and NHT models are rated as } \\
\text { the best combination to improve students' spiritual } \\
\text { and social attitudes }\end{array}$ \\
\hline A9 & $\begin{array}{l}\text { The relationship between emotional intelligence, religiosity, } \\
\text { and students' social attitudes }\end{array}$ & $\begin{array}{llr}\text { - Assessment based on components of social } \\
\text { behavior such as honesty, discipline, } \\
\text { responsibility, politeness, caring, and } \\
\text { self-confidence }\end{array}$ \\
\hline A10 & Learning social attitudes with the JiRQA learning strategy & $\begin{array}{ll} & \text { Social attitudes and descriptions can be used to fill } \\
\text { out reports on student learning outcomes }\end{array}$ \\
\hline A11 & Social attitudes to inclusive education & $\begin{array}{l}\text { There is a significant relationship between } \\
\text { emotional intelligence (X1) and students' social } \\
\text { attitudes (Y), religiosity (X2) with social attitudes } \\
(\mathrm{Y})\end{array}$ \\
\hline A12 & Social attitudes to physical education and sports & $\begin{array}{lll}\text { - There is a relationship between emotional } \\
\text { intelligence (X1) and religiosity (X2) and } \\
\text { students' social attitudes (Y) }\end{array}$ \\
\hline A13 & Validation of constructs on a general scale of social attitudes & $\begin{array}{ll}- & \text { JiRQA strategy has more potential to empower } \\
\text { students' social attitudes }\end{array}$ \\
\hline A14 & $\begin{array}{l}\text { The social attitudes of professors and students towards } \\
\text { inclusive education in tertiary institutions }\end{array}$ & $\begin{array}{l}\text { - } \begin{array}{l}\text { Students with three different ethnicities in each } \\
\text { learning strategy have different attitudes due to } \\
\text { acculturation and cultural assimilation }\end{array} \\
\end{array}$ \\
\hline A15 & $\begin{array}{l}\text { Test the validity, practicality, and effectiveness of the social } \\
\text { studies learning model based on local wisdom to improve } \\
\text { students' knowledge and social attitudes }\end{array}$ & $\begin{array}{l}\text { - The social studies learning model based on local } \\
\text { wisdom is declared valid, practical, and effective }\end{array}$ \\
\hline A16 & A qualitative study of students' social attitudes in class & $\begin{array}{l}\text { - Based on the research results, there are several } \\
\text { social attitudes found in the learning process in the } \\
\text { classroom, including being honest, disciplined, } \\
\text { responsible, caring, polite, and confiden.t }\end{array}$ \\
\hline A17 & Superflex learning model in various research results & $\begin{array}{l}\text { - Innovative learning models are very dependent on } \\
\text { teacher creativity in arousing student motivation } \\
\text { The Superflex learning model can be an } \\
\text { inspiration for teachers in designing innovative } \\
\text { learning }\end{array}$ \\
\hline
\end{tabular}


Apart from these two topics, the development and validation of social attitude instruments is also a significant issue in the research. The development of social attitude instruments was carried out by [55] for elementary school students in Indonesia. While Milas et al. [58] tested the construct validation of the questionnaire to measure students' social attitudes through self-assessment and peer assessment in Croatia. Furthermore, a qualitative study was carried out by Setiawan and Suardiman [59] who tried to describe the process of assessing social attitudes in elementary school students.

Research, which is part of research \& development, was also conducted by Uge et al. They develop a learning model based on local wisdom to increase students' knowledge and social attitudes [60]. This study examines the level of validity, practicality, and effectiveness of the development product in a social study learning model based on local wisdom. As a result, the learning model was declared valid, practical, and effective based on expert judgment, teacher responses, and students' learning test results. Research and development is a cutting-edge type of research that is considered perfect in detecting learning needs in the field and then providing solutions through the products it produces [61] [62] [63].

In the pursuit approach, epistemological beliefs and the role of mediation are also topics studied by Ghufron [64]. This research attempts to prove that epistemological beliefs and mediation of the learning approach's role for students' tolerance attitudes are one type of social attitude. The study uses three types of scales consisting of a scale of tolerance, a scale of learning approaches in Islamic Studies, and a scale of epistemological beliefs. This research's theme can be said to be a unique theme because it is different from other themes in this literature review.

Social attitudes associated with participation in physical education and sports are an essential issue raised by Goral [65] in his research. The main point in the spotlight is family support for sports education from a gender perspective. Also, other matters regarding the support of wealthy or low-income families in sports education are the main focus of this research. This study concludes that the majority of families in Turkey provide support for boys to enter sports education. Furthermore, this study also resulted in the finding that wealthy families tended to be more supportive of their children to get into sports compared to low-income families there.

The next theme raised in this review is the relationship between three different aspects: emotional intelligence, religiosity, and social attitudes. Survey research on this theme was conducted by Firdaos [66] to examine the relationship between the three variables. The results of this study indicate a significant relationship between emotional intelligence (X1) and students' social attitudes (Y) and religiosity (X2) with students' social attitudes (Y) Other results suggest that there is a significant relationship between emotional intelligence (X1) and religiosity (X2) and students' social attitudes (Y).

Furthermore, two other studies raised the theme of qualitative studies and liberty to get a real picture in learning student social attitudes. Sarwono et al. [67] stated that in the learning process in grade V Elementary School Tenggales, Kudus, Indonesia, the students showed several social attitudes. Some examples of social attitudes found in this study include honesty, discipline, responsibility, care, courtesy, and self-confidence. Also, Rachmah et al. [55] researched literature studies related to innovative learning models focused on improving aspects of students' social attitudes. The study results indicate that the Superflex learning model is considered capable of positively affecting students to enhance their social attitudes.

Based on the findings section's description that analyzes the 17 selected articles, they can be grouped into three main topic groups. The three groups are (a) learning social attitudes using a particular learning approach, (b) developing and validating instruments to assess social attitudes, and (c) issues of social attitudes in the context of inclusive education. Although other topics were highlighted in the selected articles, the numbers were not dominant. This proves that the trend of learning social attitudes is a topic that is mostly raised by researchers.

Social attitudes earning is an important issue that continues to receive attention from educators, especially in Indonesia. Of the selected articles discussing the learning of social attitudes, the majority came from Indonesian researchers. Learning social attitudes is always integrated into certain subjects because the current 2013 curriculum has placed social competence in habituation activities through teachers' examples in everyday life. Social learning is much integrated through learning approaches such as cooperative learning models with several types, JiQRA strategies, role-playing, etc. This is in line with the statement by Maasawet [68] which states that the learning model has a significantly different effect on students' social attitudes. Even specifically, Slavin [69] claims that the use of cooperative learning models has the potential to develop students' social attitudes such as tolerance, respect, and interpersonal relationships

Another issue that needs attention for researchers in the process of assessing social attitudes in schools. Several articles reviewed the development and validation of instruments to measure students' social attitudes during the learning process, using either a scale or a questionnaire. Research and development (R \& D) used by researchers aim to develop learning products in social attitude instruments to make them better than existing tools. Like the cognitive domain, social attitudes as one of the affective domains need to be comprehensively assessed [70]. The affective domain is an essential part of children's development to build their social environment [71].

As we know, all schools today continue to compete to 
produce high grades academically. Unfortunately, on the other hand, the moral decline continues to occur [72]. The learning of social attitudes must continue to be developed. In fact, many teachers have applied effective knowledge (social attitudes) through experience, but they have little knowledge of whether affective learning contributes significantly to cognitive aspects [73]. To fill this gap, several researchers conducted a qualitative study on the implementation of learning social attitudes. The findings put forward by Setiawan and Suardiman [59] are contradictory to the facts put forward by Sowel, which states that the process of assessing social attitudes is in accordance with the guidelines in the 2013 Curriculum in Indonesia.

Apart from general schools, learning social attitudes must also be applied to an inclusive school environment. There are three selected articles that discuss learning social attitudes or people's perceptions in relation to students with special needs/inclusive education. Social attitudes are needed not only by normal children but for children with special needs. Children who do not have good social attitudes will be less disciplined and have relatively low awareness and responsibility [74] [75]. In fact, the trend in children and adolescents today is towards auto-aggressive, which is an expressive form that has a negative impact on their lives [76], [77]. Therefore, there should be no different treatment between normal children and children with special needs in terms of learning social attitudes in their respective schools.

Education and learning of social attitudes have long been the focus of research by experts. However, in the last ten years, the quantity of research articles in this field has been minimal. This condition certainly makes the minimum number of references about social attitudes so that teachers, teachers, and lecturers have difficulty obtaining knowledge and information about the importance of this aspect. In the future, more research songs on social attitudes are needed so that the educational process is not only focused on cognitive aspects alone. It is hoped that the complexity of learning social attitudes can spur experts and researchers to reach a wider scope in further research.

\section{Conclusions}

There are three domains: education and learning goals, namely the cognitive, affective, and psychomotor aspects. The three of them play an equally important role in the development process of students. Although experts have emphasized the importance of these three aspects, many educators and educational institutions focus more on one aspect only. From various literature, it is the cognitive aspect that has received the dominant portion of the learning process in all parts of the world.

Social attitude is one aspect of the affective aspect that plays an essential role in the success of every individual's life. As with the cognitive aspects, social attitudes need to be integrated into the learning process to develop their social attitudes well. The amount of research on education and learning about social attitudes is still relatively low. During the past ten years, only 17 research articles met the criteria to be analysed to obtain an overview of trends and implications for learning social attitudes. Many articles discuss the theme of social attitudes, but they are not related to education and learning.

From these 17 articles, it can be said that there are several main topics raised by the researchers. It uses learning models to improve students' social attitudes, develop and validate instruments in measuring students' social attitudes, implement social attitudes in schools, and learn social attitudes in inclusive education. The four main topics provide an overview of research trends on teaching $\&$ learning social attitudes in schools and universities. The diversity of research topics does indicate positive things. However, the minimal number of studies on this field needs to be of great concern to teachers, lecturers, researchers, and the government. Although there are indications that social attitudes have been applied in the current learning system, in reality, there are still many schools that prioritize cognitive aspects in their primary goals. In the future, researchers need to explore other aspects that need to be proven through research so that social attitudes are as important as other aspects.

\section{REFERENCES}

[1] H. Helaluddin and A. Alamsyah, "Kajian Konseptual tentang Social-emotional Learning (SEL) dalam Pembelajaran Bahasa," Al-Ishlah: Jurnal Pendidikan, vol. 11, no. 1, pp. 1-16, 2019.

[2] I. Zakrisson and B. O. Ekehammar, "Social Attitudes and Education: Self-selection or Socialization?," Scandinavian Journal of Psychology, vol. 39, no. 2, pp. 117-122, 1998.

[3] A. Rodrigues, E. M. L. Assmar, and B. Jablonski, Social Psychology. Petropolis: Vozes, 2010.

[4] J. P. Torres and E. G. Mendes, "Social Attitudes and Initial Teacher Education for Special Education," Revistra Brasileira de Educacao Especial, vol. 25, no. 4, pp. 711-726, 2019.

[5] T. Arifah Nurdin, M. Japar, and I. G. Bachtiar, "Improving Social Attitudes and Knowledge through Role Playing Method," American Journal of Educational Research, vol. 6, no. 7, pp. 1040-1045, 2018.

[6] H. A. Ahmadi, Psikologi Sosial. Jakarta, Indonesia: Rineka Cipta, 2002.

[7] P. Parke and Clarke-Stewart, Social Development. New York: Wiley, 2011.

[8] A. G. Maklakov, "Personal Adaptation Potential: Its Mobilization and Predicting in Extreme Conditions," 
Psychological Journal, vol. 2, pp. 29-54, 2001.

[9] M. S. Bialangi, S. Zubaidah, M. Amin, and A. Gofur, "Development of Students Social Attitudes in Biology Classroom Through Jigsaw and Guided Inquiry," International Journal of Academic Research and Development, vol. 1, no. 10, pp. 1-7, 2016.

[10] M. R. Baidhowi, "Instrumen Penilaian Sikap Sosial (Studi Penilaian Sikap Sosial pada Mata Pelajaran Fikih di Jurusan Teknik dan Bisnis Sepeda Motor SMK Muhammadiyah 1 Patuk)," Edudeena, vol. 2, no. 1, pp. 41-56, 2018.

[11] S. Nurasiah, "Meningkatkan Sikap Sosial melalui Penerapan Model Pembelajaran Value Clarification Technique," Al-Aulad: Journal of Islamic Primary Education, vol. 2, no. 1, pp. 84-92, 2019.

[12] D. Nasution, "Mengembangkan Sikap Sosial anak Usia 5-6 Tahun dengan Metode Pembelajaran Kooperatif," Jurnal Usia Dini, vol. 2, no. 1, pp. 35-46, 2016.

[13] I. N. Hardiani and N. S. Wardani, "Pengembangan Instrumen Penilaian Sikap Sosial Pembelajaran IPS Kelas IV SD," E-journal Mitra Pendidikan, vol. 1, no. 6, pp. 615628, 2017.

[14] B. S. Arifin, Psikologi Sosial. Bandung: Pustaka Setia, 2015.

[15] T. Dayakisni and Hudainah, Psikologi Sosial. Malang, Indonesia: Universitas Muhammadiyah Malang (UMM) Pres, 2009.

[16] S. Azwar, Penyusunan Skala Psikologi. Yogyakarta: Pustaka Belajar, 2015.

[17] Sudarsono, Kamus Konseling. Jakarta, Indonesia: Rineka Cipta, 2014.

[18] K. T. Reid, P. Trofimovich, and M. G. O'Brien, "Social Attitudes and Speech Ratings: Effects of Positive and Negative Bias on Multiage Listeners Judgemnents of Second Language Speech," Studies in Second Language Acquisition, pp. 1-24, 2018.

[19] P. J. Corr, S. Hargreaves-Heap, K. Tsutsui, A. Russell, and C. Seger, "Personality and Social Attitudes: Evidence for Positive-approach Motivation," Personalities and Individual Differences, vol. 55, pp. 846-851, 2013.

[20] E. Purwakarti, "Pengaruh Model Collaborative Learning terhadap Kemampuan Pemecahan Masalah Matematika dan Sikap Sosial Siswa Kelas V SD Jarakan," Jurnal Penelitian Ilmu Pendidikan, vol. 8, no. 1, pp. 95-111, 2015.

[21] H. Wijaya and A. Arismunandar, "Pengembangan Model Pembelajaran Kooperatif Tipe STAD Berbasis Media Sosial," Jurnal Jaffray, vol. 16, no. 2, pp. 175-196, 2018.

[22] H. Helaluddin and A. Fransori, "Integrasi The Four CS dalam Pembelajaran Bahasa," Eduhumaniora: Jurnal Pendidikan Dasar, vol. 11, no. 2, pp. 95-106, 2019.

[23] K. S. Dwi, "Pentingnya Pendidikan Moral bagi Anak Sekolah Dasar," Dinamika Pendidikan, vol. XIV, no. 1, pp. 118-130, 2007.

[24] S. Marlina, "Peningkatan Sikap Sosial Anak Usia Dini melalui Permainan Puzzle Buah di Taman Kanak-kanak Aisyiyah 1 Bukittinggi," Pedagogi: Jurnal Ilmu Pendidikan, vol. 14, no. 2, pp. 109-114, 2014.
[25] Kunandar, Penilaian Autentik: Penilaian Hasil Belajar Peserta Didik Berdasarkan Kurikulum 2013. Jakarta, Indonesia: Rajawali Press, 2014.

[26] S. Mutafidoh and E. W. Wibowo, "Analisis Pelaksanaan Penilaian Sikap Sosial Siswa Berdasarkan Kurikulum 2013," Primary: Jurnal Keilmuan dan Kependidikan Dasar, vol. 9, no. 1, pp. 79-92, 2017.

[27] D. Pati and L. N. Lorusso, "How to Write a Systematic Review of the Literature," Health Environment Research and Design Journal, vol. 20, no. 10, pp. 1-16, 2017.

[28] M. J. Grant and A. Booth, "A Typology of Reviews: An Analysis of 14 Review Types and Associated Methodologies," Health Infoormation and Libraries Journal, vol. 26, pp. 91-108, 2009.

[29] S. V. N. Rante, H. Helaluddin, Hengki Wijaya, H. Tulak, and U. Umrati, "Far from Expectation: A Systematic Literature Review of Inclusive Education in Indonesia," Universal Journal of Educational Research, vol. 8, no. 11B, pp. 6340 6350, 2020.

[30] J. Jin and S. Bridges, "Qualitatives Research in PBL in Health Sciences Education: A Review," Interdisciplinary Journal of Problem-based Learning, vol. 10, pp. 1-28, 2016.

[31] D. Transfield, D. Denyer, and P. Smart, "Towards a Methodology for Developing Evidence-based-informed Management Knowledge bty Means of Systematics Review,' British Journal of Management, vol. 14, no. 3, pp. 207-222, 2003.

[32] H. Helaluddin, Hengki Wijaya, M. Guntur, Z. Zulfah, and S. Syawal, "Digital Immigrants Versus Digital Natives: A Systematic Literature Review of The 'Ideal Teacher' in Disruptive Era," in Borderless Education as a Challenge in the 5.0 Society: Proceedings of the 3rd International Conference on Educational Sciences (ICES 2019), November 7, 2019, Bandung, Indonesia, 2020, pp. 212-218.

[33] A. Fink, Conducting Research Literature Review: From The Internet to Paper, 3rd Editio. Thousand Oaks, USA: SAGE Publication, 2010.

[34] B. G. Ríos, F. L., \& Casal, "Standards for The Preparation and Writing of Psychology Review Articles," International Journal of Clinical Psychology, vol. 9, no. 2, pp. 329-344, 2009.

[35] A. Booth, D. Papaioannu, and A. Sutton, Systematic Approaches to A Succesfull Literature Review. London, UK: Sage Publication, 2012.

[36] D. Moher, A. Liberati, J. Tetzlaff, and D. G. Altman, "Preferred Reporting Items for Systematic Reviews and Meta-analysis: The PRISMA Statement," PloS Medicine, vol. 151, no. 4, pp. 264-269, 2009.

[37] P. W. Handayani, "Systematic Review dengan PRISMA (preferred Reporting Items for Systematic Reviews and Meta-analysis)," 2017. [Online]. Available:dosen.perbanas. id/up-content/uploads/2017/08/sesi2-SYSTEMATIC-REVI EW-DENGAN-PRISMA.pdy. [Accessed: 23-Aug-2020].

[38] P. Danese, V. Manf, and P. Romano, "A Systematic Literature Review on Recent Lean Research: State-of-the-art and Future Directions," International Journal of Management Review, vol. 20, pp. 579-605, 2018. 
[39] A. H. T. Tan, B. Muskat, and A. Zehrer, "A Systematic Review of Quality of Student Experience in Higher Education," International Journal of Quality and Service Sciences, vol. 8, no. 2, pp. 209-228, 2016.

[40] M.S. Ramirez and F.J. Garcia-Penalvo, "Co-creation and Open Innovation: Systematic Literature Review," Comunicar, vol. XXVI, no. 54, pp. 9-18, 2018.

[41] J. Kasperiuniene and V. Zydziunaite, "A Systematic Literature Review on Professional Identity Construction in Social Media," Sage Open, vol. January-Ma, pp. 1-11, 2019.

[42] R. Acton, "Mapping the Evaluation of Problem-oriented Pedagogies in Higher Education: A Systematic Literature Review," Educ. Sci., vol. 9, pp. 2-23, 2019.

[43] D. Moher, A. Liberati, J. Tetzlaff, and D. G. Altman, "Preferred Reporting Items for systematic Reviews and Meta-analysis: The PRISMA Statement," PloS Med., vol. 6, no. 7, 2009.

[44] P. Mozelius and E. Hettiarachchi, "Critical Factors for Implementing Blended Learning in Higher Education," ICTE J., vol. 6, no. 1, pp. 4-18, 2017.

[45] A. A. Selcuk, "A Guide for Systematic Reviews: PRISMA," Turkish Arch. Otorhinolaryngol., vol. 57, no. 1, pp. 57-58, 2019.

[46] A. Raes, L. Detienne, I. Windey, and F. Depaepe, "A Systematic Literature Review on Synchronous Hybrid Learning: Gaps Identified," Learn. Environ. Res., 2019.

[47] M. I. Zakaria, S. M. Maat, F. Khalid, and S. Approach, "A Systematic Review of M-learning in Formal Education," Int. J. of, Creat. Chang., vol. 7, no. 11, pp. 1-24, 2019.

[48] A. McFadden and K. E. Williams, "Teachers as Evaluators: Results from a Systematic Literature Review," Stud. Educ. Eval., vol. 64, no. December 2019, pp. 1-17, 2020.

[49] M. Calik, S. Unal, B. Costu, and F. O. Karatas, "Trends in Turkish Science Education," Essays Educ., vol. Special Ed, pp. 23-45, 2008.

[50] S. Elo and H. Kyngas, "The Qualitative Content Analysis Process," J. Adv. Nurs., vol. 62, no. 1, pp. 107-115, 2008.

[51] H. W. Hardaningtiastuti, A. T. Soegito, and M. M., "The Development of Social Attitudes through Cooperative Learning Methods in Social Studies Education Subjects in Public Junior High School 1 Batang," J. Educ. Soc. Stud., vol. 7, no. 2, pp. 217-223, 2018.

[52] Tri Supartini, Ivan Th. J. Weismann, Hengki Wijaya, and Helaluddin Helaluddin, "Development of Learning Methods through Songs and Movements to Improve Children's Cognitive and Psychomotor Aspects," Eur. J. Educ. Res., vol. 9, no. 4, pp. 1615-1633, 2020.

[53] Y. Bustami, A. D. Corebima, E. Suarsini, and Ibrohim I., "The Social Attitude Empowerment of Biology Students: Implementation JiRQA Learning Strategy in Different Ethnics," Int. J. Instr., vol. 10, no. 3, pp. 15-30, 2017.

[54] S. Bachtiar, S. Zubaidah, A. D. Corebima, and S. E. Indriwati, "The Spiritual and Social Attitudes of Students towards Integrated Problem Based Learning Models," Issues Educ. Res., vol. 28, no. 2, pp. 254-270, 2018.
[55] H. Rachmah, R. Gunawan, and J. H. Hendrawan, "Superflex: Innovative Learning to Develop Social Attitude Competencies," Int. J. Elem. Educ., vol. 2, no. 1, pp. 66-71, 2018.

[56] M. De Caroli and E. Sagone, "Professional self and Social Attitudes towards Disability: A Comparison between Curricular and Special Needs Teachers," Int. J. Dev. Educ. Psychol. INFAD. Rev. Psicol., vol. 1, no. 4, pp. 493-500, 2011.

[57] J. A. Brunhara et al., "Accessibility of People with Disabilities to Higher Education: Social Attitudes of Students and Professors of A Higher Education Institutions," Rev. Cefac Speech, Lang. Hear. Sci. Educ. J., vol. 21, no. 3, 2019.

[58] G. Milas, B. Mlacic, and I. Miklousic, "Construct validation of a General Social Attitudes Scale," J. Individ. Differ., vol. 34, pp. 203-213, 2013.

[59] A. Setiawan and S. P. Suardiman, "Assessment of the Social Attitude of Primary School Students," Res. Eval. Educ., vol. 4, no. 1, pp. 12-21, 2018.

[60] S. Uge, A. Neolaka, and M. Yasin, "Development of Social Studies Learning Model Based on Local Wisdom in Improving Students' Knowledge and Social Attitude," Int. J. Instr., vol. 12, no. 3, pp. 375-388, 2019.

[61] Sugiyono, Metode Penelitian \& Pengembangan Research Development. Bandung: Alfabeta, 2016.

[62] H. Helaluddin, M. A. Ahmad, and A. Anshari, "Need analysis of academic writing teaching model based on process-genre approach: What do they really need?," Univers. J. Educ. Res., vol. 8, no. 10, pp. 4728-4735, 2020.

[63] H. Helaluddin, “Analisis Kebutuhan dalam Redesain Silabus (RPS) Mata Kuliah Bahasa Indonesia di Perguruan Tinggi," Jurnal Gramatika: Jurnal Penelitian Pendidikan Bahasa dan Sastra Indonesia, vol. 4, no. 1, pp. 85-104, 2018.

[64] M. Nur Ghufron, "Epistemological Beliefs and Mediating Role of Learning Approaches on Social Attitudes of SHS Students," Universal Journal of Educational Research, vol. 8, no. 1, pp. 202-211, 2020.

[65] M. Goral, "Social Attitudes of Turkish Students towards Participation in Physical Education and Sport," Social Behavior Personality, vol. 38, no. 9, pp. 1243-1260, 2010.

[66] R. Firdaos, "Emotional Intelligence, Religiosity, and Social Attitude of Students," Jurnal Pendidikan Islam, vol. 3, no. 1, pp. 45-56, 2017.

[67] A. Y. Sarwono, M. Murtono, and E. Widianto, "The Teacher's Role in Developing Student Social Attitudes," International Journal of Elementary Education, vol. 4, no. 3, pp. 384-391, 2020.

[68] E. T. Maasawet, Effect of Cooperative Learning Strategies Snowbaling and Numbered Heads Together (NHT) at the School of Multi-ethnic Against Critical Thinking Skills, Cognitive Science Learning Outcomes Bilogy anf Social Attitudes Junior High School Students Samarinda. Malang: University of Malang, Indonesia, 2009.

[69] R. E. Slavin, Cooperative Learning: Theory, Research and Practice. Bandung, Indonesia: Nusa Media, 2010. 
[70] D. B. McCoach, R. K. Gable, and J. P. Madura, Instrument Development in The Affective Domain: School and Corporate Application. New York: Springer, 2013.

[71] C. A. Dwyer, "Assessment and Classroom Learning: Theory and Practice," Assessment in Education: Principle, Policy, \& Practice, vol. 5, 1998. doi: 10.1080/0969595980050109

[72] J. M. Kuboja and B. M. Ngussa, "Affective Learning and Cognitive Skills Improvement: Experience of Selected Schools in Arusha, Tanzania," International Journal of Academic Research in Progressive Education \& Development, vol. 4, no. 2, 2015.

[73] E. J. Sowel, Curriculum: An Integrative Research. New Jersey: Prentice-Hall, 2005.

[74] A. Kanioglov, H. Tsorbatzoudis, and V. Barkoukis, "Socialization and Behavioral Problems of Elementary
School Pupils with Developmental Coordination Disorder," Perceptual and Motor Skills, vol. 101, pp. 163-173, 2005.

[75] A. Setiawan, D. Mardapi, Supriyoko, and D. Andrian, "The Development of Instrument for Assessing Students' Affective Domain Using Self- and Peer-assessment Models," International Journal of Instruction, vol. 12, no. 3, pp. 425438, 2019.

[76] O. V. Zakrevskaja, "Features of Value Orienttions of Teenagers," System of Contemporary Society Values, vol. 29, pp. 97-103, 2013.

[77] V. B. Salakhova, A. A. Oschepkov, N. V. Lipatova, P. V. Popo, and I. V. Mkrtumova, "Features of Social Attitudes and Value Orientations of Youths and Adolescents Prone to Auto-aggressive Behavior," International Journal of Environmental and Science Education, vol. 11, no. 16, pp. 9017-9025, 2016. 